\title{
Work and Labor in Slow-Progressive Sectors of the Economy
}

\section{Matti Vuorensyrjä}

Senior Planning Officer, Research and Development, Police College of Finland ${ }^{1}$

\begin{abstract}
In the late 1960s, William Baumol demonstrated that structurally unbalanced growth, with the associated cost disease phenomenon, can be expected to have some very particular effects on work and labor in slow-progressive sectors of the economy: performing arts, health care, education, and law enforcement. Specifically, there will be downward pressure on the rate of growth of unit wages and upward pressure on the rate of growth of productivity in these sectors. In the long run, the effects of cost disease are potentially damaging for work and labor in some of the key human service occupations in the public sector.

In this interdisciplinary paper, we put forward a simple model, which reconstructs and renews the model discovered by Baumol in 1967. Our model makes only a minor modification to Baumol's original cost disease model, but the implications of this modification are noteworthy. They are also largely unexplored in empirical research. In this paper, we search for empirical traces of the effects of cost disease on work and labor. We use earlier economic and social scientific research literature on inter-industry wage differences and on time pressure, and we analyze differences in work orientations with the help of the ISSP Work Orientations III data set. Our empirical findings are early and rough intimations. However, they do give preliminary support to the propositions of the paper. The observed changes in employment, wages, and experienced time pressure all correspond to what we would expect on the basis of the cost disease hypothesis. The same applies to the observed differences in the structure of incentives across different occupational groups. The paper is not empirically conclusive, but we see it as a basis for interesting further research.
\end{abstract}

\section{KEY WORDS}

Cost disease / unbalanced growth / heterogeneity of labor / pay satisfaction / time pressure / intrinsic motivation

\section{Introduction}

D aumol and Bowen $(1965 / 1997,1966)$ pointed out in their classic inquiries into the economic difficulties characteristic of performing arts ${ }^{1}$ that the conditions of work in the performing arts differ from the conditions of work in other economic activities. For a majority of performing artists, though certainly not for all, ${ }^{2}$ leading a life of a performing artist meant constant struggle for earning a living. However hard

\footnotetext{
${ }^{1}$ Research and Development, Police College of Finland, PO BOX 123, 33721 Tampere, FINLAND. Contact (preferred): Department of Management Studies, School of Management, 33014 University of Tampere, FINLAND. E-mail: matti.vuorensyrja[at]uta.fi.
} 
they tried, and however low they kept the costs of their own company, it appeared that they were fighting a losing battle. In terms of the current paper, they were under the twin pressures characteristic of the slow-progressive sectors of the economy: downward pressure on the rate of growth of wages and upward pressure on the rate of growth of productivity.

Baumol and Bowen $(1965 / 1997,1966)$ were equally careful in pointing out that this had some very specific effects on labor in the slow-progressive sectors of the economy, i.e., on the workers who opted for a career in the performing arts and decided to stay in the field. They enjoyed music, for instance, and got deep psychic income from their chosen art. In terms of modern theories of motivation, they appreciated the intrinsic motivational aspects of their occupation, rather than the extrinsic incentives involved with it (Deci and Ryan, 1985; Ryan and Deci, 2000).

There are two parts to this paper. In the first part, we present a simple model which reconstructs and renews the argument by Baumol and Bowen. The theoretical discussion in this paper focuses on the effects of cost disease on unit wages, productivity pressure, and the structure of incentives in slow-progressive economic activities. Earlier research has focused on other kinds of implications of the cost disease phenomenon. The emphasis has been on the contraction of the overall rate of growth of the economy in the long run, the problems concerned with the overall tax rate of the economy, and the associated problems of sustainable social spending. In view of different industries, earlier analyses cover at least performing arts, health care, education, mass media, computing technology (hardware, software), and law enforcement and military (see Baumol, 1967, 1993a, 1993b, 1996, 2012; Baumol and Baumol, 1984/1997; Baumol and Bowen, 1965/1997, 1966; Baumol and Oates, 1972/1997; Baumol et al., 1985; Besharov, 2005; Cowen, 1996; Fordham, 2003; Lindbeck, 2006; Nordhaus, 2002, 2006; Oulton, 2001; Peacock, 1996; Preston and Sparviero, 2009; Scitovsky and Scitovsky, 1959; Sparviero and Preston, 2010; Triplett and Bosworth, 2003; van der Ploeg, 2006; van Reenen, 1999).

In the second part of the paper, we take a brief, early look at the empirical evidence. We analyze the effects of cost disease on the nature of work and working conditions in the slow-progressive economic activities. First, we briefly revisit the literature on inter-industry wage differentials. Then, in a bit more detailed analysis, we consider the predicted effects of cost disease on productivity pressure and on intrinsic vs. extrinsic incentives. We ask and aspire to answer the following:

1. What happens to employees' experience of time pressure in an economy which experiences a massive shift of employment from agriculture and manufacturing industries to labor-intensive services, with opportunities for labor-augmenting technological improvements tapering off?

2. If time pressure, as a manifestation of productivity pressure, shoots up as expected, and if wages in the slow-progressive sectors are lagging behind other sectors, why is it that the supply of labor does not collapse in the slow-progressive sectors?

3. Does the actual, observed structure of incentives correspond to the expected structure of incentives, in the sense that intrinsic incentives are accentuated in the occupations of the slow-progressive sectors, compared with the occupations of the fast-progressive sectors? 


\section{Cost disease}

Growth of productivity is one of the stylized facts of economic growth. However, the rate of growth of productivity is different in different economic activities. It is relatively low in labor-intensive services with limited opportunities to labor-augmenting technological change, and it is relatively high in capital-intensive manufacturing industries with rich opportunities for such improvements (Clark, 1957; Kuznets, 1973; Maddison, 1982, 1991).

In terms of Baumol (1967), the former are the "non-progressive" sectors of the economy, whereas the latter are the "progressive" sectors. The non-progressive sectors of the economy can be expected to be plagued by the so-called cost disease. In these sectors, the real unit costs grow on a continuous basis.

Baumol's (1967) Macroeconomics of Unbalanced Growth: The Anatomy of Urban Crisis formalized the idea with the help of a relatively simple macroeconomic model. Baumol stated, as his opening words to the article, that "There are some economic forces so powerful that they constantly break through all barriers erected for their suppression." He proposed to deal with a mechanism, which, he thought, “(...) has colored the past and seems likely to stamp its character on the future" (Baumol 1967, p. 415).

According to Baumol (1967), growth is systematically unbalanced because the rates of growth of productivity are different in different sectors of the economy. The systematic nature of the differences relates to the function of labor in the process of production. It relates to whether or not labor is "(...) itself the end product," and not merely "(...) an incidental requisite for the attainment of the final product (...)” (Baumol, 1967, p. 416). The former kinds of activities constitute the non-progressive sector of the economy, while the latter kinds of activities form the progressive sector. Baumol actually assumed that, in the non-progressive sector, there would be no productivity growth at all. Irrespective of this, he also assumed that the rates of growth of wages in the two sectors would be the same. Baumol's results were highly dependent on these two assumptions, but they are not as restrictive as they may appear at first sight. We will actually relax the wage rate assumption here in this paper.

Based on the results of his model, Baumol (1967) suggested that

1. The cost per unit of output of the non-progressive sector will rise without limit.

2. All except the highly price inelastic (and/or highly income elastic) outputs of the non-progressive sector will decline, and some of them will disappear altogether.

3. Nevertheless, if and in so far as the ratio of the outputs between the progressive and the non-progressive sectors will be held constant, the non-progressive sector will suck and employ an ever larger share of the total labor force of the economy.

4. If the non-progressive sector displays a zero rate of growth of productivity and if, at the same time, the total labor force remains constant, the overall rate of growth of the economy will asymptotically approach zero (Baumol, 1967, pp. 418-419).

According to Baumol (1967), only the municipalities—the local government sector-are capable of supporting some of the most important non-progressive political economic activities. These include, among other services, health care, education, and law enforcement.

Macroeconomics of unbalanced growth thus called forth the anatomy of urban crisis. Slower-than-average growth of productivity and faster-than-average growth of unit 
costs would chronically strain municipalities. An ever-greater share of the labor force would be drawn into the public sector, particularly to public services. Gradually, but inevitably, the overall economic growth of political economies would first slow down and then die out. The developments will attract offsetting institutional changes, but, according to Baumol (1967, p. 423), the trend in the real costs of municipal services cannot be stopped.

But note that it is not impossible to keep to the non-progressive core public services. In fact, the rising real costs of non-progressive economic activities constitute no problem at all, provided the citizens are prepared to reallocate their spending correspondingly. They can afford these services. This is written into the model assumptions: the productivity of the economy is improving. This, of course, does not do away with the fact that the process of reallocation will have to be incessant; it will have to be a permanent part of the way the political economy functions (Baumol, 1992/1997, 1993a, 1993b, 1996; Baumol and Baumol, 1985/1997).

The propositions of the current paper prevail on the condition that reallocationgrowing public support for the non-progressive core public services-combines with other measures, fiscal and monetary discipline in the public sector, and varied, persistent efforts to improve productivity in public services. There is realism, we presume, to our conditional propositions. According to the early appraisal by Tibor and Anne Scitovsky (1959), "Whatever the reason, these services have become dearer compared to other goods; and this fact, combined with the public's reluctance to spend more on them, has occasionally led to the reduction in their supply or worsening of their quality" (Scitovsky and Scitovsky, 1959, p. 102; see also Baumol, 1993a, pp. 23-27).

\section{Tax rate and differential wage rates in a model of unbalanced growth}

In the original model by Baumol (1967), the rates of growth of wages in the two sectors were the same. This was unrealistic, perhaps, but it would have been equally unrealistic to assume that the rate of growth of wages in the slow-progressive sector was zero.

There is a third alternative, which actually corresponds to the early intimation by Baumol and Bowen (1966) as probably the most realistic assumption as regards the development of wages in the slow-progressive sector. Having considered the two other alternatives, Baumol and Bowen went on to write: "There is a third alternative, which, in fact, comes closest to what we find in practice. Wages of performers do rise, but they do not always manage to keep up with wages in the rest of the economy. (...) Even in the long run, earnings in the performing arts may lag behind wages in occupations which provide less in the way of psychic income" (Baumol and Bowen 1966, p. 169; cf. Nordhaus, 2006, p. 28, footnote 22; cf. also Baumol and Throsby, 2012).

In Appendix B of this paper, we take a more formal look at the argument. Baumol's (1967) model will be updated with both tax rate of the economy (following Lindbeck's (2006) model) and differentially growing wage rates for the two sectors. Formalizing the idea reveals an interesting domain of parameters, with high taxes and two coexistent pressures.

Essentially, the model in Appendix B demonstrates that there is an analytically feasible and empirically plausible domain of parameters in which 
1. the tax rate of the economy reaches its all-time high, when, at the same time,

2. employees in the slow-progressive sector suffer from lower-than-average wages and when, still in the same domain of parameters,

3. the organizations and employees in the sector have to deal with persistent and often stern productivity pressure.

Readers interested in formal analysis will probably benefit from the model depicted in Appendix B, but for all practical purposes, the three hypotheses (1-3) derived from the model suffice to do the trick.

Empirically, there are probably many intervening factors making it difficult to sort out the exact effects on the affected, slow-progressive economic activities, ${ }^{3}$ but, analytically, the following question seems to be not only legitimate but also very interesting. Are work and labor in the "laggard services, (...) health care, education, legal services, welfare programs for the poor, postal service, police protection, sanitation, repair services, the performing arts and restaurants" (Baumol 1992/1997, p. 507) really featured by the characteristics, predicted by the cost disease model (see Appendix B)?

\section{The cost disease model-some second thoughts}

The empirical evidence by and large agrees with what the cost disease model predicts, ${ }^{4}$ but there are also scholars who have not been convinced by the cost disease argument. ${ }^{5}$ Given the extent of the existing literature on the cost disease hypothesis (see, for example, the special issue on the hypothesis in the Journal of Cultural Economics, Volume 20, Issue 3, 1996; the anthology by Towse (ed.), 1997; the scholarly history on the subject by Besharov, 2005; and the most recent review of the intellectual field by Baumol, 2012), we cannot tackle all objections to the cost disease model here in this paper. We settle for taking a look at two critical discussions concerning the hypothesis.

1) The first type of critique of the cost disease model has to do with the impact of technological innovations on the supposedly non-progressive services. There are several distinct human services that seem to have been capable of escaping the cost disease trap. The development of technology, especially under the auspices of modern information and communication technologies (ICTs), has profound and often unforeseeable effects on the structure of the economy. Significant productivity improvements have suddenly become possible in many distinct sectors of the performing arts (recording devices, the Internet, and new mobile technologies and applications), health care (medication, new techniques in, e.g., surgery), teaching (distance education), and law enforcement (automatic surveillance).

In analyzing the "new economy" (ICT), Nordhaus (2002) and Triplett and Bosworth (2003) decomposed the productivity growth statistics of the U.S. economy. What they found was an unexpected, robust upturn in the productivity statistics around the mid-1990s. The upturn was economy-wide in the sense that it was not restricted to the new economy (industrial and electronic machinery (semiconductors)). Productivity in the retail and the wholesale trade in particular had also improved. This was unexpected, especially after the marked productivity slowdown from the mid-1970s to the mid-1990s. Nordhaus and Triplett and Bosworth interpreted this as meaning that "Baumol's Disease Has Been Cured" (Triplett and Bosworth, 2003; see also Nordhaus, 2002, 
p. 228, and passim; Preston and Sparviero, 2009; Sparviero and Preston, 2010; cf. also Nordhaus, 2006).

Critics of the cost disease hypothesis were not surprised by these findings. According to Tyler Cowen (1996, p. 208), in cultural economic activities, the continuous stream of new recording technologies (long-playing records, compact discs, the radio, and jukebox) clashes with the cost disease argument. Cowen emphasizes, along with his core argument, that the cost disease model neglects quality improvements on the output side and that it thus fails to properly account for productivity improvements in cultural economic activities. Also, according to Cowen, empirical tests of the cost disease hypothesis have concentrated on the opera, theater, and symphony orchestra, ignoring the underground winners of the field: rock and roll, country music, heavy metal, rave, techno, and rap. In fact, according to Cowen, empirical evidence from the United States on live performances of the classics does not support the cost disease model (Cowen, 1996, p. 211).

In an earlier paper, Baumol et al. (1985) had actually tackled some of these questions head-on. According to Baumol and others, the cost disease phenomenon will invade any and all attempts at improving productivity in labor-intensive, slow-progressive sectors of the economy. This is because the share of the progressive component can be expected to shrink over time in view of both expenditures and labor time, and what will be left, in the long run, will be the non-progressive component. Cowen (1996) is familiar with the argument, but not convinced by it. The development of recording technologies cannot be considered as a once-and-for-all impact on performing arts; Cowen (1996, p. 208) argues that recording technologies continuously improved throughout the 20th century.

Preston and Sparviero (2009; Sparviero and Preston, 2010) distinguish between the analytically different components of the value chain of cultural economic activities. In their opinion, the content component and the distribution component should be kept apart in empirical analysis. ${ }^{6}$ With this in mind, they went on to estimate the development of output, output per worker, unit labor cost, and labor compensation in "pure form activities" and "composite content and form activities" in the U.S. economy from 1987 to 2004 (Preston and Sparviero, 2009). In another article, they looked at the development of the U.S. economy from 1990 to 2003, concentrating on the growth of productivity, the relative sizes, and the interaction between "stagnant and asymptotically stagnant industries" and "progressive industries" (Sparviero and Preston, 2010).

The estimates by Preston and Sparviero go a long way toward settling the controversy. On the basis of their empirical analyses, it appears that there really are both stagnant industries, in which improvements in productivity have been sporadic rather than continued, and progressive industries, which are characterized by a continuous stream of improvements in productivity. According to Preston and Sparviero (2009, p. 245), Cowen (1996) was right in pointing out that there can be marked improvements in productivity in the service industries. Performance output in particular, when measured in consumption units, can experience a marked increase. That is to say, there are progressive services. According to Sparviero's and Preston's (2010, p. 1911) estimates, these include the following: the wholesale trade, the retail trade, transportation and warehousing, publishing industries, broadcasting and telecommunications, securities, commodity contracts and investments, insurance carriers and related activities, funds, trusts, and other financial vehicles. In this respect, Oulton (2001), and subsequently also Baumol (2012, pp. 120-126), has emphasized the importance of the rapidly expanding business services sector. 
However, there are also stagnant and "asymptotically stagnant" (a term originally coined by Baumol et al., 1985) industries. According to Sparviero and Preston (2010, p. 1911), these industries include legal services, administrative and support services, educational services, ambulatory health-care services, hospitals and nursing and residential care facilities, social assistance, government, and the performing arts.

Hence, even if certain qualifications need to be taken into account for the cost disease hypothesis, the key conclusions of the cost disease model appear to hold true. This is also the conclusion by Preston and Sparviero (2009, p. 250; "The trends revealed by our analysis are highly consistent with the assumptions we formulate based on W. J. Baumol's theories") and Sparviero and Preston (2010, p. 1910; “The key estimates resulting from this model, (...) confirm our analysis and the continuing salience of Baumol's theory"). ${ }^{7}$

Subsequently, also Nordhaus (2006; cf. Nordhaus, 2002) took another look at what he calls "Baumol's diseases." He differentiated between six distinct propositions derived from the cost disease model. The empirical results presented by Nordhaus gave strong support to the key propositions of the cost disease model, with, however, one single and significant exception. This was the proposition according to which industry-specific rewards (wages, profits) respond to the industry-specific rates of growth of productivity. Nordhaus found that this particular effect was very small. ${ }^{8}$

2) The second major current of scholarly discussion on the cost disease model concerns the financial sustainability of social spending. Is the welfare state, which provides the bulk of core human services, financially sustainable? According to Mark Blaug (2001, p. 131), Baumol's own view on this particular matter changed during the course of his career (see Michael Keren's critical account of the original cost disease model; Keren, 1972/1997; consider Baumol's answer to Keren, in Baumol, 1972/1997; and see also Baumol, 1992/1997, 1993a, 1993b, 1996, 2012, pp. xvii-xix, 181-182). Baumol's (1967) original ideas were more pessimistic in tone than his subsequent assessments. Later on, Baumol (1992/1997) was ready to admit that "A Growing Economy Can Pay Its Bills." In a recent book written in cooperation with other scholars, Baumol (2012) is actually quite optimistic about the future.

The topic continues to be an important part of the ongoing political economic debate on the future of the welfare state. How important, exactly, is the cost disease phenomenon compared with other problems that are known to cause financial difficulties in the public sector (globalization, moral hazard and benefit dependency, demographic changes in the Western political economies and in Japan, the current financial crisis in the United States and in the European Union)? How will the political economies actually respond to the growing real costs of the labor-intensive public services? What will happen to the (price and) income elasticity of the demand for human services in the long run?

Lindbeck (2006) provides a comprehensive review of the threats to sustainable social spending. ${ }^{9}$ According to Lindbeck (2006, p. 304), the years of rapid economic growth and structural change from the late 1940s to the mid-1970s were "highly conducive" to the growth of the welfare state around the Western world. The period was characterized not only by robust economic growth in the West but also by a growing demand for welfare services by the citizenry, a favorable demographic structure with a relatively small number of people in elderly cohorts, low unemployment rates, and relatively few disincentive effects. 
Many of these factors began to change at the beginning of the 1970s with the slowing down of economic growth. Lindbeck (2006) discusses the following threats to sustainable social spending:

a) Globalization;

b) Baumol's cost disease;

c) Demographic changes, especially in the form of the "graying" of the population;

d) Slower productivity growth in the private sector than before;

e) Threat of diminished employment rates; and

f) Changes in the structure of incentives, including moral hazard and benefit dependency.

Tertium quid is an obvious problem when dealing with complex political economic problems in which micro- and macroeffects are intertwined. We cannot easily rule out the possibility that there are third factors that explain the same observations as the cost disease hypothesis.

Lindbeck's own estimate is straightforward enough: "I argue that threats from gradually rising costs of providing human services and disincentive effects of welfare state arrangements, in particular moral hazard and benefit dependency, are more difficult to deal with than other threats" (Lindbeck, 2006, p. 303). His conclusion is that, sooner or later, governments will need new, complementary methods of financing the core human services in addition to traditional tax financing: service fees, voluntary or mandatory insurance, and mandatory savings accounts (Lindbeck, 2006, pp. 309, 319).

The current financial crisis in the European Union puts emphasis on measures other than tax financing, especially on strict financial discipline, productivity improvements in the public sector, and major structural reforms in public organizations. Yet, it must be kept in mind that what is at stake here is development in the long run and in the aggregate. The contemporary situation may require financial discipline rather than tax financing, but things can turn out to be different in the future. It is difficult, and it may be impossible, to know how the structure of the preferences of the citizenry will respond to price and income changes in the coming years.

\section{Pressure readings}

\section{Inter-industry wage differentials}

Findings on inter-industry wage differentials are consistent with the cost disease model depicted in Appendix B. The differentials are persistent and stable, both over time and across different countries. Gittleman and Wolff (1993) compared the differentials across 14 OECD countries. They not only found that there is relatively robust rank order stability in inter-industry wage differentials but also found that there are obvious similarities in the actual wage structures across different countries.

This, in itself, is perplexing from the point of view of the standard competitive textbook models of the demand for and supply of labor. Why are the differentials so stable over time and so similar across different countries? Should not rational optimizing behavior wipe the differentials out, at least in the long run? Controlling for worker and job characteristics—unobserved ability, job content, compensating differences, etc.-reduces the 
scale of observed inter-industry wage differentials, but does not suffice to eliminate them (Gibbons and Katz, 1992; Gittleman and Pierce, 2011; Krueger and Summers, 1988).

According to Gittleman and Wolff (1993), the dogged differentials are positively related to an interesting series of macroeconomic quantities. These are labor productivity growth, the total factor productivity growth, GDP growth, capital intensity (capital/ labor ratio), and the degree of export orientation of the economy.

It probably should not come as a great surprise, against this background, that the differentials come out as expected. In empirical inter-industry wage comparisons, retail trade, hotels and restaurants, personal and domestic services, social welfare services, child care, educational services, and maybe even health care (on average, but admittedly as a less clear-cut case) suffer from lower-than-average wages (Gibbons and Katz, 1992; Gittleman and Pierce, 2011; Gittleman and Wolff, 1993; Krueger and Summers, 1988; Reilly and Zanchi, 2003; cf., however, Nordhaus, 2006, p. 28, footnote 22, pp. 28-30, 38).

\section{Time pressure}

"The high productivity and consequent high cost of labor have made people increasingly conscious of the fact that time is money; (...) It is only natural that the pace of work should be speeded up." (Scitovsky and Scitovsky, 1959, p. 101)

Productivity pressure comes in many different, and even disguised, forms for the affected industries, organizations, and employees. On some occasions, it might actually be difficult to recognize the beast.

Time pressure is one of the potential, straightforward consequences of productivity pressure..$^{10}$ It can be expected to plague health care and personal care, in particular, where presence and attendance, and often very intensive care, are necessary for the quality of the end product.

In view of the development of time pressure over time, as experienced by employees in different sectors of the economy, Finland provides us with a graphic case. Economic growth in Finland was exceptionally robust from the early 1960s to the late 1980s. It was associated with equally strong expansion of employment in public services, particularly in health care, child care, care for the elderly, and education. ${ }^{11} \mathrm{~A}$ truly massive share of employment shifted from manufacturing industries and agriculture to services. Figure 1 depicts employment in primary, secondary, and tertiary industries in Finland from 1966 to 2010 . The number of people employed in tertiary industries went up from $811,000(37.6 \%$ in 1966$)$ to $1,762,000(72.0 \%$ in 2010$)$.

What happened to time pressure, as experienced by employees in different sectors of the economy, over this time period? If nothing whatsoever happened to time pressure, - a distinct manifestation of productivity pressure in health care, child care, care for the elderly, etc., - - then, this certainly could be considered as evidence against the cost disease model as depicted in this paper.

Statistics Finland produces comprehensive statistics on work and working conditions in the Finnish economy. There are representative cross-section surveys with reliable time pressure instruments from 1977 to 2008 (Lehto and Sutela, 2008; Quality of Work Life Surveys, QWLS, 1977, 1984, 1990, 1997, 2003, 2008). ${ }^{12}$ One of the key advantages 
Figure I: Employment in primary, secondary, and tertiary industries in Finland, 1966-2010.

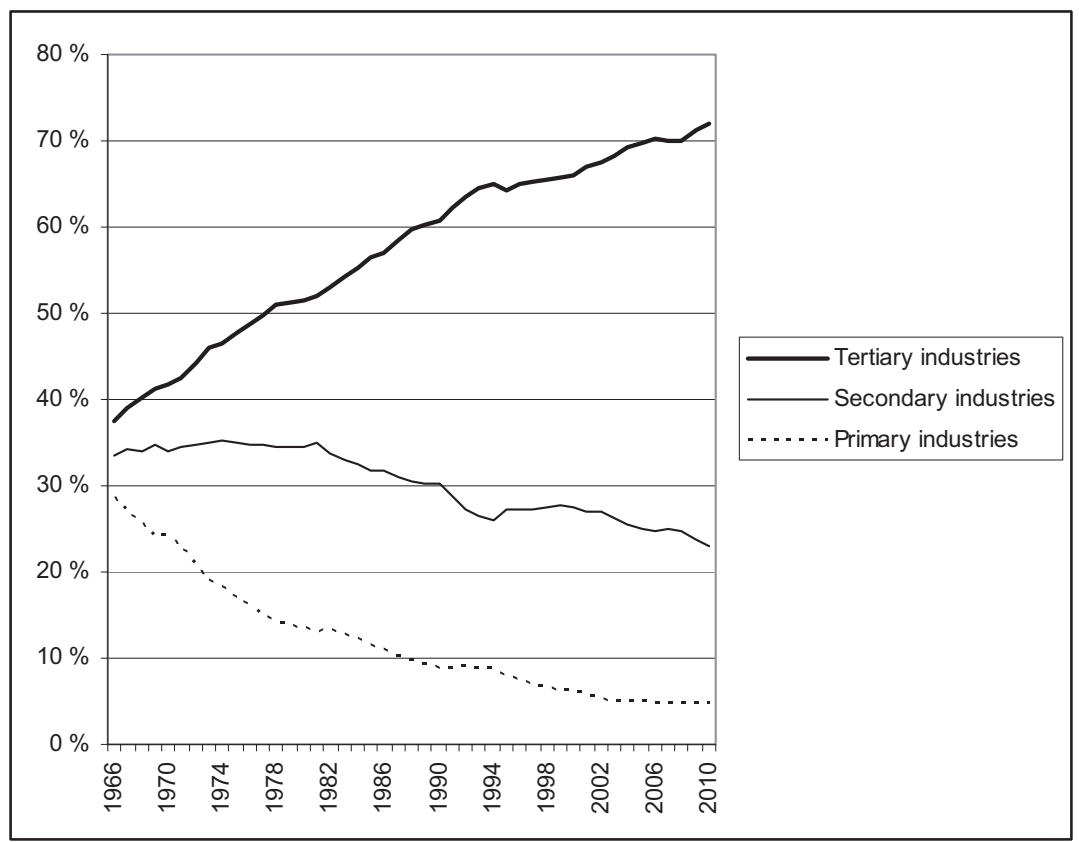

Source: Finnish Labour Review I/201 I,Tables.

of the surveys is that a major part of the questions in the QWLS have remained largely the same since the first years of the surveys.

According to Lehto and Sutela (2008), the share of respondents who suffer from adverse effects of time pressure ("very much" or "quite a lot") has gone up from $18 \%$ (1977) to $31 \%$ (2008). In the municipalities, the share has gone up from $24 \%$ (1984) to $38 \%$ (2008) (Lehto and Sutela, 2008, p. 68). ${ }^{13}$

In Finland, the bulk of personal care work, work in health care, and teacher's work (primary and secondary education) is handled in the local government sector, and it is the local government sector that suffers the most from time pressure. Using eight indicators from the time pressure instrument of the QWLS, and the cross-section data from 2008, Lehto and Sutela (2008) were able to sort out the sectors of the economy suffering the most from time pressure. Their dichotomous criterion variable picked up the respondents for whom five of the eight key variables of the time pressure instrument were at a high level. Workers in the local government sector were found to suffer the most from time pressure (41\%). In other sectors (private sector, central government), the corresponding figures were around $30 \%$.

In a more disaggregated level of analysis, Lehto and Sutela (2008) found that employees in occupations of health care suffered the most from time pressure $(52 \%)$, followed by employees in teaching $(48 \%)$ and in public sector management $(48 \%)$. The figures were lowest in construction (21\%), agriculture (18\%), and manufacturing $(16 \%)$ (Lehto and Sutela, 2008, p. 72). 
The phenomenon of time pressure, as measured in the QWLS, is clearly something disadvantageous from the point of view of an individual employee. It is a personal cost. This becomes clear when taking a glance at the way the respondents in these surveys conceive of the key causes and consequences of time pressure.

According to the respondents of the QWLS (2008), one of the major causes of time pressure is that there are simply too few employees at the workplace, compared with the workload. The share of employees who agree with this particular claim has gone up from $45 \%$ (1990) to $54 \%(2008)$. As to the consequences of time pressure, it is seen to cause mistakes in work. According to the respondents, it also causes burnout and poor team and organizational climate and increases the number of days of illness (Lehto and Sutela, 2008, p. 75).

\section{The Value of time}

What, then, has backed up the expansion of the supply of labor in the slow-progressive economic activities: the sectors with lagging wages and probably also a heightened push for productivity? Baumol and Bowen (1965/1997, 1966; Baumol and Throsby, 2012) offered one plausible reason, in vein of compensating differences: the psychic income a musician associates with his or her career in music. There could be other comparable reasons, caused by differences in individual preferences. Public service motivation is another candidate for the role. It has been under intense scholarly research in public management studies in recent years (Coursey and Pandey, 2007; Perry, 1996; Perry and Wise, 1990).

However, even if we allow for between-sector differences in individual preferences, the problem remains that, if the ratio of outputs between the progressive and nonprogressive sectors will be held constant, the non-progressive sector will have to employ an ever larger share of the total labor force of the economy. This means that, in the long run, any and all surplus of intrinsic incentives there is will be exhausted and eaten up.

There is one dynamic factor, which probably backs up the supply of labor in the slow-progressive sectors. It has to do with the relative value of time, which can be expected to grow with the growth of per capita income.

Time is a fixed resource in life, and very strictly so. Name almost any other entity, and we can produce more of it. But not time. As a consequence, the more affluent the society, the scarcer, relatively to all other goods, time is, and the more willingly people would want to buy time, if ever they could. People cannot purchase time, as such, but there are indirect means for accomplishing the feat.

The choice of occupation is one of the tools that people use for this purpose. The more affluent the society, the more willingly people substitute an interesting job, even with low-income and low-employment opportunities (meaningful occupation, leisurely time, personal consumption), for a dull job, even with high-income and high-employment opportunities (meaningless occupation, laborious time, personal investment). By doing this, they actually trade off relatively high-income and low-unemployment-risk dull jobs (laborious time, characteristic of the sometimes very difficult and demanding scientific, engineering, economic, etc. occupations) for relatively low-income and high-unemployment-risk interesting jobs (leisurely time, characteristic of occupations in performing arts, humanities, philosophy, etc.). 
We certainly do not suggest that high (low)-income occupations are invariably uninteresting (interesting). The claim is, rather, that, instead of merely selling their labor time to employers, irrespective of the nature of the occupation, employees consider whether or not they want to spend eight hours, or a month, or some 40 years, in the occupation. Very few of us can actually substitute a hobby for a job (as a 100\% substitution of leisure time for labor time), but, to a certain degree, intrinsic motives to work do constitute a factor which affects the choice of occupation, ${ }^{14}$ and we have a very good reason to believe that, the more affluent the society, the more important this factor will be, compared with other factors.

Intrinsic motives to work and the psychic income obtained thereof are not restricted to the liberal arts or to what is often referred to as "high culture," or the "fine arts." In the public sector, we come across intrinsic motives to work in rather mundane occupations. Helping other people, as a central example, is part of the concept of public service motivation (Perry, 1996; Perry and Wise, 1990), and, in view of the definition of intrinsic motivation (Ryan and Deci, 2000, p. 56), it is certainly an intrinsic rather than an extrinsic motive to work. There are actually straightforward empirical grounds to support the claim. If we look at the factor structure of the work orientations inventory in the ISSP Work Orientations III (2005) data set, "helping other people" clearly differs from extrinsic incentives to work, and it turns out that it is relatively important to child-care workers, primary education teaching professionals, and police officers, among other public sector professionals (discussed in more detail below).

All the same, we admit that there are also occupations in slow-progressive services in which intrinsic motives play only a minor role or no role at all. Restaurant and hotel work, cleaning, institutional household services, repair work, and retail work may serve as examples. Whether or not this is actually the case,-implying the growth of the share of precarious rather than professionally agreeable employment-is an empirical question. Theoretically, we certainly acquiesce to this possibility. ${ }^{15}$

Our data come from the international ISSP Work Orientations III (2005) survey, which contained eight questions on the personally important aspects of work. The respondents were asked whether or not "high income," "an interesting job," and "helping other people," among other considerations, were personally important to them $(1=$ very important; 5 = not important at all).

In a simple factor analysis (EFA, PAF, Promax, $\kappa=4$, using the weights of the data set), the variable of high income had the largest loading to a construct which could be depicted as the factor of extrinsic incentives (with "opportunity to advancement" and "job security"), whereas the variable of helping other people had the largest loading to a construct which could be depicted as the factor of public service motivation (with "a job useful to society"). The variable of an interesting job penetrated the factor solution with significant side loadings to both of the above-mentioned constructs. However, because the reliability of the scale of extrinsic incentives was too low (by the criteria of $\alpha$ and $\operatorname{VAR}(F)$ ), we decided to use the indicator variables with the highest loadings, and not the latent variables, in the analysis.

Figure 2 exhibits the relationship between GDP per capita (from Penn World Tables, PWT 7.0, 2011) and the ratio of the personal importance of high income to interesting job, across 30 different countries. ${ }^{16}$ In nine countries out of 30 , the respondents valued high income relatively more than an interesting job (i.e., the ratio was $>1.0$ ). Eight of these nine countries belonged to the group of the poorest nine countries. $R^{2}$ of the simple linear regression was 0.69 . 
Figure 2: GDP per capita* and personally important aspects of work across 30 different countries contained in the ISSP 2005 data. $^{.}$

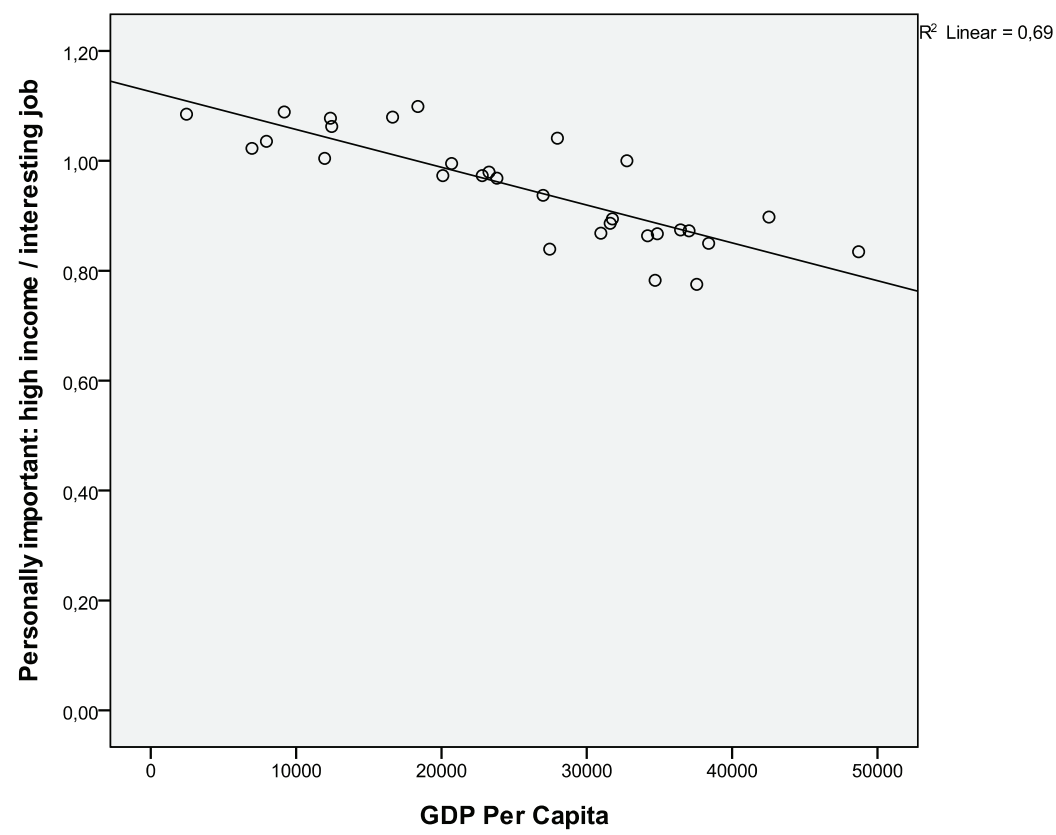

*PPP Converted GDP Per Capita (Laspeyres), derived from growth rates of c, g, i, at 2005 constant prices.

${ }^{a}$ Note that the original scale of the survey $(I-5: I=$ very important; 5 = not important at all) was reversed in drawing Figure 2, to make it graphic.

Data sources: Penn World Tables, PWT 7.0, 20 I I, GDP per capita 2005; ISSP Work Orientations III 2005 (weighted).

Wages and time pressure tip the scale against the occupations in the slow-progressive sectors of the economy. Intrinsic interest in music, dance, health care, personal care, teaching, law enforcement, etc., has the opposite kind of effect. It is quite possible, and probable even, that regularities, such as the one depicted in Figure 2, are among the factors that enable developments such as the spectacular, massive process depicted in Figure 1.

The rough, aggregate empirical observations on employment, wages, time pressure, and the development of the intrinsic vis-à-vis extrinsic incentives, along with economic growth, are consistent with the predictions of the cost disease hypothesis. Next, we will take a comparative look at the structure of incentives in different occupations in a more detailed, disaggregated level of analysis.

\section{Intrinsic motives and extrinsic incentives}

With the help of the ISSP Work Orientations III (2005) survey data, consisting of 43,440 respondents from 32 different countries, it will be possible to compare the work 
orientations of different occupational groups to one another in a very detailed manner. Our primary interest here is in health care and personal care (particularly nursing and midwifery professionals, child-care workers, institution-based personal care workers, and home-based personal care workers), teaching (particularly primary education teaching professionals and secondary education teaching professionals, but also college, university, and higher education teaching professionals), performing arts (particularly musicians and singers, choreographers and dancers, ${ }^{17}$ and film, stage, and related actors and directors), and law enforcement (particularly police officers). These occupational groups most obviously represent employees in labor-intensive services, with little or no opportunity for labor-augmenting technological improvements.

In view of intrinsic motivation and extrinsic incentives, we expect that, for the above-mentioned occupational groups:

h1-1: high income would be personally less important than for all occupations, on average;

h1-2: an interesting job would be personally more important than for all occupations, on average;

h1-3: helping other people would be personally more important than for all occupations, on average, particularly in health care, personal care, teaching, and law enforcement.

We computed country-specific $z$-scores for three distinct variables of personally important aspects of work, using the ISSP Work Orientations III (2005) data set: "high income," "an interesting job," and "help other people." That is to say, the distributions were $(0,1)$-standardized for each country, the resulting $z$-scores reflecting standardized country-specific means and country-specific deviations from the mean. With such a series of $z$-scores, we compared the scores of the different occupational groups to the norm score (zero) across all occupations in all countries.

The results of the exercise are reported in Appendix A, Tables A1-A3, for 18 different occupational groups (ISCO 1988, 4-digit classification). In Table 1, which compiles the results, we take a look at the means from the particular point of view of our hypotheses ( $h 1-1, h 1-2$, and $h 1-3)$. The table tells us that 17 out of 30 means were in the expected direction, with a statistically significant difference from the norm score (*); 10/30 means were in the expected direction, with no statistically significant difference from the norm score $(+)$; and 3/30 means were in the unexpected direction, with no statistically significant difference from the norm score $(-) .{ }^{18}$

Almost all of the means of the different occupational groups were observed to be in the right direction (i.e., as expected) when comparing the occupational group scores to the norm scores (zero). There were three exceptions to this.

One of the exceptions was formed by the group of police officers. They do value an interesting job, and it is personally important for police officers to be able to help other people, but it appears that they also value high income, perhaps even more so than other people in general. Another exception was formed by home-based personal care workers. It appears that an interesting job is not more important to home-based personal care workers than to people in other occupations in general, perhaps even less so. They do think, however, more than others on average, that it is important to be able to help other people. The third exception was perhaps the easiest to understand. It appears that, to be able to help other people, is not a personally important aspect of work for "film, stage and related actors and directors", not at least to any extraordinary degree. 
Table I Personally important aspects of work by occupational groups: classification of the results. ${ }^{a}$

\begin{tabular}{|c|c|c|c|}
\hline & $\begin{array}{l}\text { High income, expected } \\
\text { to be less important } \\
\text { than on average }\end{array}$ & $\begin{array}{c}\text { An interesting job, } \\
\text { expected to be more } \\
\text { important than on } \\
\text { average }\end{array}$ & $\begin{array}{l}\text { Help other people, } \\
\text { expected to be more } \\
\text { important than on } \\
\text { average }\end{array}$ \\
\hline $\begin{array}{l}\text { Nursing and midwifery } \\
\text { professionals }\end{array}$ & + & * & * \\
\hline Child-care workers & * & + & * \\
\hline $\begin{array}{l}\text { Institution-based personal care } \\
\text { workers }\end{array}$ & + & + & * \\
\hline $\begin{array}{l}\text { Home-based personal care } \\
\text { workers }\end{array}$ & + & - & * \\
\hline $\begin{array}{l}\text { Primary education teaching } \\
\text { professionals }\end{array}$ & + & * & * \\
\hline $\begin{array}{l}\text { Secondary education teaching } \\
\text { professionals }\end{array}$ & * & * & * \\
\hline $\begin{array}{l}\text { College, university, and higher } \\
\text { education teaching professionals }\end{array}$ & * & * & + \\
\hline $\begin{array}{l}\text { Composers, musicians, and } \\
\text { singers }\end{array}$ & + & * & + \\
\hline $\begin{array}{l}\text { Film, stage, and related actors } \\
\text { and directors }\end{array}$ & + & * & - \\
\hline Police officers & - & * & * \\
\hline
\end{tabular}

+Mean in the expected direction, with no statistically significant difference from the norm score.

*Mean in the expected direction, with statistically significant difference from the norm score.

-Mean in the unexpected direction, with no statistically significant difference from the norm score.

${ }^{a}$ For a closer account of the results, see Appendix A.

\section{Conclusions}

In this article, we put forward a simple formal model, which reconstructed, in a slightly renewed form, the model of unbalanced growth, originally devised by William Baumol (1967). The model demonstrated that there is an analytically feasible and empirically plausible domain of parameters in which the tax rate of the economy reaches its all-time high; in which employees in the slow-progressive sector suffer from lower-than-average wages; and in which the organizations and employees in the slow-progressive sector are forced to struggle with persistent productivity pressure. If the political mechanism of the economy fails to keep up with required measures of reallocation, the cost disease phenomenon will give rise to downward pressure on the rate of growth of unit wages and upward pressure on the rate of growth of productivity in the slow-progressive sectors of the economy. 
The paper was theoretical in nature, but we also took a brief look at a few interesting empirical observations. We are the first to admit that the findings are but early, rough, empirical intimations. However, they did give preliminary support to the propositions of the paper, or at least they did not belie the propositions.

The observed changes in employment, wages, experienced time pressure, and the relative value of time, with the growth of per capita income, all correspond to what we would expect on the basis of the cost disease hypothesis. The same applies to the observed differences in the structure of incentives across different occupational groups. Intrinsic and extrinsic incentives, as measured in the ISSP Work Orientations III (2005) data set, were almost unexceptionally consistent with the big picture.

Part of the innovativeness of the current paper resides in the fact that these particular aspects of the cost disease hypothesis-the effects on unit wages, productivity pressure, and the structure of incentives in slow-progressive economic activities-have been largely unexplored in earlier empirical research. Earlier research has focused on other kinds of implications of the cost disease phenomenon: the contraction of the overall rate of growth of the economy in the long run, problems concerning the overall tax rate of the economy, and the associated problems of sustainable social spending.

While the highly aggregate approaches characteristic of earlier research are perfectly acceptable as such, we argue that something is missing from the picture. There is a structural aspect to the political economy and political economic actors. Economic growth, structural change, specialization, and deepening heterogeneity of work, labor, and human capital all go hand in hand.

When an economy grows, it experiences structural change. At the same time, it becomes ever more subtly specialized and structured. ${ }^{19}$ The labor factor of production becomes differentiated and the different kinds of labor provide poor substitutes for each other in production. In addition to "homogeneous labor," "homogeneous units of worker productivity," "skilled" vis-à-vis "unskilled" labor, and "homogeneous human capital," modern labor economics and human resource management studies need to be able to conceive of the different conditions and contexts of work: the "heterogeneity of labor," "heterogeneous human capital," and the occupation-specific drivers of motivation.

In this paper, we also briefly reflected upon some of the most common objections to the cost disease hypothesis. The effects of technological innovations on the structure of the economy are unforeseeable, and it has been suggested that there are services industries that have been capable of actually escaping the cost disease trap. On the basis of Preston's and Sparviero's analyses, we can say that there are indeed exceptions to the cost disease rule in the sense that there are progressive services. The picture is much more complicated than it was thought to be on the basis of the original cost disease model. Yet, at the same time, it appears that practically all observations concerning core human services (health care, child care, care for the elderly, teaching, and law enforcement) still continue to correspond to the predictions of the cost disease model.

We also pointed out that the difficulties associated with the financial sustainability of social spending may become aggravated as the real costs of human services keep on rising. Universalism is one of the core differentiating characteristics of the Nordic welfare state regime (or the "Scandinavian welfare state regime," cf. Esping-Andersen, 1990, pp. 27-29). In such a system, high-quality public services are provided to all. The system is financially burdensome, because it is based on services provided to all citizens, not, essentially, on income transfer payments or mere generalized sharing of risks. All citizens 
benefit from services and all will also, "presumably (...)," as noted by Esping-Andersen (1990, p. 28) “(...) feel obliged to pay.”

The political mechanism is the decisive element here, and political decisions are certainly based on many things other than the rising costs of human services. There are several exogenous factors affecting these decisions, globalization, for example, which has a powerful effect on the overall economic growth and structure of the political economy. There are also other constraints affecting the financial sustainability of social spending, such as the problems of moral hazard and benefit dependency. Finally, there is the public demand for human services, which will also probably experience changes in the long run depending on the income (and price) elasticity of the demand for these services.

One of the most important endogenous factors is surely the quality of public services. If the quality of public services gets worse, the willingness of the citizens to pay for these services will be diminished. Erosion of the demand for, and funding of, the public services can be expected to lead to further deterioration of the quality of these services. But, obviously, also another kind of corner solution-high-quality public services with citizens strongly committed to their funding-is possible.

\section{Appendix A}

\section{Tables A I-A3}

In Tables A1-A3, we report country-specific $z$-scores for three distinct variables of personally important aspects of work. We have used the ISSP Work Orientations III (2005) data set in the analysis. The respondents assessed the personal importance of "high income" (hi), "an interesting job" (ij), and "help other people" (hop). The original scale (1-5) ranged from $1=$ very important to $5=$ not important at all. We used the weights of the data set throughout the analysis.

The original scores of the survey data were $(0,1)$ standardized for each country. Hence, the $z$-scores in the tables reflect country-specific standardized means and countryspecific standardized deviations from the mean. We use these country-specific $z$-scores when comparing the scores of the different occupational groups to the norm score (zero) across all occupations in all countries.

The procedure is simple and straightforward. It may actually be a bit too simple; it might be a good idea to rerun the analyses with the help of, for example, multilevel models or nonparametric methods. However, there are other obstacles to the multivariate models, particularly the insufficient number of observations among certain occupational groups.

Nonetheless, the procedure as it stands does provide us with information about the opinions of the respondents in certain occupations (e.g., police officers) on, say, the personal importance of "high income," on average, compared with the country means (norm scores, zeros) for that particular variable; in other words, they show us whether their opinions were on the negative side (i.e., more important), on average, compared with the country means or on the positive side (less important), on average, compared with the country means.

We report the means $(\bar{x})$, standard deviations (SD), standard errors (SE), and confidence intervals (CI) for the different occupations in the three tables. The occupation codes correspond to the ISCO (1988) 4-digit classification. 
Table AI Means of country-specific z-scores by occupational groups: "personally important: high income".

\begin{tabular}{|c|c|c|c|c|c|c|c|}
\hline Occupation & Code $^{a}$ & $N$ & $\begin{array}{c}\bar{x} \\
\text { (c.s.-z; hi) } \\
\end{array}$ & $\begin{array}{c}\text { SD } \\
\text { (c.s.-Z; hi) }\end{array}$ & $\begin{array}{c}\text { SE } \\
\text { (c.S.-Z; hi) } \\
\end{array}$ & $\begin{array}{l}95 \% \mathrm{Cl} \\
\text { Lower }\end{array}$ & $\begin{array}{l}95 \% \mathrm{Cl} \\
\text { Upper }\end{array}$ \\
\hline Medical doctors & 2221 & 136 & -0.007 & 0.918 & 0.079 & -0.163 & 0.148 \\
\hline Dentists & 2222 & 33 & -0.105 & 0.864 & 0.150 & -0.410 & 0.200 \\
\hline Veterinarians & 2223 & 20 & -0.150 & 0.912 & 0.202 & $-0.57 \mid$ & 0.272 \\
\hline Pharmacists & 2224 & 28 & 0.001 & 1.127 & 0.211 & -0.432 & 0.435 \\
\hline $\begin{array}{l}\text { Nursing and midwifery } \\
\text { professionals }\end{array}$ & 2230 & 276 & 0.086 & 0.951 & 0.057 & -0.027 & 0.198 \\
\hline Child-care workers & 5131 & 241 & $0.141 *$ & 1.058 & 0.068 & 0.007 & 0.275 \\
\hline $\begin{array}{l}\text { Institution-based } \\
\text { personal care workers }\end{array}$ & 5132 & 272 & 0.058 & 1.047 & 0.063 & -0.067 & 0.183 \\
\hline $\begin{array}{l}\text { Home-based personal } \\
\text { care workers }\end{array}$ & 5133 & 84 & 0.228 & 1.231 & 0.134 & -0.039 & 0.495 \\
\hline $\begin{array}{l}\text { Primary education } \\
\text { teaching professionals }\end{array}$ & 2331 & 314 & 0.078 & 0.869 & 0.049 & -0.018 & 0.175 \\
\hline $\begin{array}{l}\text { Secondary education } \\
\text { teaching professionals }\end{array}$ & 2320 & 459 & $0.169 *$ & 1.034 & 0.048 & 0.074 & 0.264 \\
\hline $\begin{array}{l}\text { College, university, and } \\
\text { higher education } \\
\text { teaching professionals }\end{array}$ & 2310 & 167 & $0.181 *$ & 1.065 & 0.082 & 0.018 & 0.344 \\
\hline $\begin{array}{l}\text { Authors, journalists, } \\
\text { and other writers }\end{array}$ & $245 \mid$ & 95 & $0.338 *$ & 1.078 & 0.110 & 0.119 & 0.558 \\
\hline $\begin{array}{l}\text { Sculptors, painters, } \\
\text { and related artists }\end{array}$ & 2452 & 33 & $0.409 *$ & 1.019 & 0.177 & 0.047 & 0.770 \\
\hline $\begin{array}{l}\text { Composers, musicians, } \\
\text { and singers }\end{array}$ & 2453 & 15 & 0.127 & 1.100 & 0.287 & -0.490 & 0.744 \\
\hline $\begin{array}{l}\text { Choreographers and } \\
\text { dancers }\end{array}$ & 2454 & n.r. & n.r. & n.r. & n.r. & n.r. & n.r. \\
\hline $\begin{array}{l}\text { Film, stage, and related } \\
\text { actors and directors }\end{array}$ & 2455 & 26 & 0.048 & 0.958 & 0.188 & -0.340 & 0.436 \\
\hline $\begin{array}{l}\text { Police inspectors } \\
\text { and detectives }\end{array}$ & 3450 & 33 & -0.162 & 0.813 & 0.142 & -0.451 & 0.127 \\
\hline$\underline{\text { Police officers }}$ & 5162 & 152 & -0.057 & 0.892 & 0.072 & -0.200 & 0.086 \\
\hline All occupations & Total & 33,542 & -0.008 & 0.995 & 0.005 & -0.019 & 0.003 \\
\hline
\end{tabular}

a|SCO 1988, 4 digit.

n.r. $=$ not reported, less than ten observations.

Original scale $(\mid-5): \mid$ = very important, $\ldots, 5=$ not important at all.

Data source: ISSP Work Orientations III 2005 (weighted).

$\bar{x}$ (c.s.-z; hi) mean, based on country-specific z-scores, "high income."

$* \mathrm{p}<.05$. 
Table A2 Means of country-specific z-scores by occupational groups: "personally important: an interesting job".

\begin{tabular}{|c|c|c|c|c|c|c|c|}
\hline Occupation & Code $^{a}$ & $N$ & $\begin{array}{c}\bar{x} \\
\text { (c.s.-z; ij) } \\
\end{array}$ & $\begin{array}{c}\text { SD } \\
(\text { c.s.-z; ij) }\end{array}$ & $\begin{array}{c}\mathrm{SE} \\
(\mathrm{c.s.}-Z ; i j) \\
\end{array}$ & $\begin{array}{l}95 \% \mathrm{Cl} \\
\text { Lower }\end{array}$ & $\begin{array}{l}95 \% \mathrm{Cl} \\
\text { Upper }\end{array}$ \\
\hline Medical doctors & 2221 & 136 & $-0.345 *$ & 0.728 & 0.062 & -0.469 & -0.222 \\
\hline Dentists & 2222 & 32 & -0.190 & 1.254 & 0.221 & -0.640 & 0.260 \\
\hline Veterinarians & 2223 & 20 & -0.074 & 1.067 & 0.236 & -0.567 & 0.419 \\
\hline Pharmacists & 2224 & 27 & -0.075 & 0.986 & 0.188 & -0.462 & 0.312 \\
\hline $\begin{array}{l}\text { Nursing and midwifery } \\
\text { professionals }\end{array}$ & 2230 & 278 & $-0.113^{*}$ & 0.918 & 0.055 & -0.221 & -0.004 \\
\hline Child-care workers & 5131 & 239 & -0.096 & 0.925 & 0.060 & -0.214 & 0.022 \\
\hline $\begin{array}{l}\text { Institution-based } \\
\text { personal care workers }\end{array}$ & 5132 & 273 & -0.044 & 0.951 & 0.058 & -0.157 & 0.070 \\
\hline $\begin{array}{l}\text { Home-based personal } \\
\text { care workers }\end{array}$ & 5133 & 84 & 0.107 & 1.119 & 0.122 & -0.135 & 0.350 \\
\hline $\begin{array}{l}\text { Primary education } \\
\text { teaching professionals }\end{array}$ & 2331 & 316 & $-0.238^{*}$ & 0.831 & 0.047 & -0.330 & -0.146 \\
\hline $\begin{array}{l}\text { Secondary education } \\
\text { teaching professionals }\end{array}$ & 2320 & 458 & $-0.227 *$ & 0.829 & 0.039 & -0.304 & -0.151 \\
\hline $\begin{array}{l}\text { College, university, and } \\
\text { higher education teaching } \\
\text { professionals }\end{array}$ & 2310 & 167 & $-0.410 *$ & 0.764 & 0.059 & -0.526 & -0.293 \\
\hline $\begin{array}{l}\text { Authors, journalists, and } \\
\text { other writers }\end{array}$ & 2451 & 97 & -0.146 & 1.169 & 0.119 & -0.382 & 0.089 \\
\hline $\begin{array}{l}\text { Sculptors, painters, and } \\
\text { related artists }\end{array}$ & 2452 & 33 & -0.145 & 1.052 & 0.183 & -0.519 & 0.228 \\
\hline $\begin{array}{l}\text { Composers, musicians, } \\
\text { and singers }\end{array}$ & 2453 & 15 & $-0.465^{*}$ & 0.670 & 0.175 & $-0.84 \mid$ & -0.089 \\
\hline $\begin{array}{l}\text { Choreographers and } \\
\text { dancers }\end{array}$ & 2454 & n.r. & n.r. & n.r. & n.r. & n.r. & n.r. \\
\hline $\begin{array}{l}\text { Film, stage, and related } \\
\text { actors and directors }\end{array}$ & 2455 & 26 & $-0.409 *$ & 0.758 & 0.149 & -0.716 & -0.102 \\
\hline $\begin{array}{l}\text { Police inspectors and } \\
\text { detectives }\end{array}$ & 3450 & 33 & -0.156 & 0.808 & 0.141 & -0.443 & 0.131 \\
\hline Police officers & 5162 & 149 & $-0.200 *$ & 0.874 & 0.071 & -0.341 & -0.059 \\
\hline All occupations & Total & 33,544 & -0.009 & 0.987 & 0.005 & -0.020 & 0.001 \\
\hline
\end{tabular}

ISCO 1988, 4 digit.

n.r. $=$ not reported, less than ten observations.

Original scale $(\mid-5): \mid=$ very important, $\ldots, 5=$ not important at all.

Data source: ISSP Work Orientations III 2005 (weighted).

$\bar{x}$ (c.s.-z; ij) $\sim$ mean, based on country-specific z-scores, "interesting job." $* \mathrm{p}<.05$. 
Table A3 Means of country-specific z-scores by occupational groups: "personally important: help other people".

\begin{tabular}{|c|c|c|c|c|c|c|c|}
\hline Occupation & Code $^{a}$ & $N$ & $\begin{array}{c}\bar{x} \\
\text { (c.s.-z; hop) } \\
\end{array}$ & $\begin{array}{c}\text { SD } \\
\text { (c.s.-z; hop) }\end{array}$ & $\begin{array}{c}\mathrm{SE} \\
\text { (c.S.-Z; hop) } \\
\end{array}$ & $\begin{array}{l}95 \% \mathrm{Cl} \\
\text { Lower }\end{array}$ & $\begin{array}{l}95 \% \mathrm{Cl} \\
\text { Upper }\end{array}$ \\
\hline Medical doctors & 2221 & 137 & $-0.44 \mid *$ & 0.851 & 0.073 & -0.585 & -0.297 \\
\hline Dentists & 2222 & 33 & $-0.723 *$ & 0.668 & 0.116 & -0.959 & -0.487 \\
\hline Veterinarians & 2223 & 20 & 0.061 & 1.051 & 0.232 & -0.425 & 0.546 \\
\hline Pharmacists & 2224 & 28 & -0.202 & 0.957 & 0.179 & -0.570 & 0.166 \\
\hline $\begin{array}{l}\text { Nursing and midwifery } \\
\text { professionals }\end{array}$ & 2230 & 277 & $-0.445 *$ & 0.765 & 0.046 & -0.535 & -0.354 \\
\hline Child-care workers & 5131 & 240 & $-0.294 *$ & 0.869 & 0.056 & -0.405 & -0.184 \\
\hline $\begin{array}{l}\text { Institution-based personal } \\
\text { care workers }\end{array}$ & 5132 & 274 & -0.55 । & 0.863 & 0.052 & -0.654 & -0.448 \\
\hline $\begin{array}{l}\text { Home-based personal } \\
\text { care workers }\end{array}$ & 5133 & 84 & $-0.332 *$ & 0.972 & 0.106 & -0.542 & -0.121 \\
\hline $\begin{array}{l}\text { Primary education } \\
\text { teaching professionals }\end{array}$ & 2331 & 316 & $-0.287 *$ & 0.852 & 0.048 & -0.381 & -0.193 \\
\hline $\begin{array}{l}\text { Secondary education } \\
\text { teaching professionals }\end{array}$ & 2320 & 453 & $-0.260 *$ & 0.837 & 0.039 & -0.338 & -0.183 \\
\hline $\begin{array}{l}\text { College, university, } \\
\text { and higher education } \\
\text { teaching professionals }\end{array}$ & 2310 & 167 & -0.103 & 0.947 & 0.073 & -0.248 & 0.042 \\
\hline $\begin{array}{l}\text { Authors, journalists, and } \\
\text { other writers }\end{array}$ & 2451 & 94 & 0.061 & 0.983 & 0.101 & -0.140 & 0.262 \\
\hline $\begin{array}{l}\text { Sculptors, painters, and } \\
\text { related artists }\end{array}$ & 2452 & 33 & 0.250 & 0.935 & 0.163 & -0.082 & 0.581 \\
\hline $\begin{array}{l}\text { Composers, musicians, } \\
\text { and singers }\end{array}$ & 2453 & 15 & -0.194 & 0.605 & 0.158 & -0.533 & 0.145 \\
\hline $\begin{array}{l}\text { Choreographers and } \\
\text { dancers }\end{array}$ & 2454 & n.r. & n.r. & n.r. & n.r. & n.r. & n.r. \\
\hline $\begin{array}{l}\text { Film, stage, and related } \\
\text { actors and directors }\end{array}$ & 2455 & 26 & 0.097 & 0.966 & 0.190 & -0.294 & 0.488 \\
\hline $\begin{array}{l}\text { Police inspectors } \\
\text { and detectives }\end{array}$ & 3450 & 33 & $-0.426 *$ & 0.732 & 0.128 & -0.686 & -0.166 \\
\hline Police officers & 5162 & 149 & $-0.217 *$ & 0.907 & 0.074 & -0.363 & -0.070 \\
\hline All occupations & Total & 33,385 & -0.008 & 0.993 & 0.005 & -0.019 & 0.003 \\
\hline
\end{tabular}

aISCO 1988, 4 digit.

n.r. $=$ not reported, less than ten observations.

Original scale $(\mid-5): \mid$ = very important, $\ldots, 5=$ not important at all.

Data source: ISSP Work Orientations III 2005 (weighted).

$\bar{x}$ (c.s.-z; hop) $\sim$ mean, based on country-specific $z$-scores, "help other people."

$* \mathrm{p}<.05$. 


\section{Appendix B}

\section{Tax rate and differential wage rates in a model of unbalanced growth}

\section{Tax rate}

Assar Lindbeck's (2006) model of unbalanced growth includes tax rate $(\tau)$ for the funding of public services. Otherwise, it largely corresponds to Baumol's (1967) classic formulation for the model.

In Lindbeck's (2006) model, the slow-progressive sector of the economy produces human services in the public sector $\left(Q_{1 t}\right)$, whereas the fast-progressive sector produces goods in the private sector $\left(Q_{2 t}\right)$. Homogeneous labor employed in the two distinct sectors $\left(L_{1 t}, L_{2 t}\right)$ constitutes the only factor of production in the economy. The rate of growth of productivity is higher in the fast-progressive sector $(r)$ compared with the slow-progressive sector $(\rho), r>\rho$. The rate of growth of wages $\left(W_{t}\right)$ is the same across the two sectors. It is given by the rate of growth of productivity in the fast-progressive sector, $r$. The development of output and wages over time $(t)$ is given by equations (1), (2), and (3).

$$
\begin{gathered}
Q_{1 t}=a e^{\rho t} L_{1 t} \\
Q_{2 t}=b e^{r t} L_{2 t} \\
W_{t}=W e^{r t}
\end{gathered}
$$

Unit costs are given by equations (4) and (5), and total costs by equations (6) and (7), both pairs of equations written in terms of the different sectors of the economy.

$$
\begin{gathered}
C_{1 t}=\frac{W_{t} L_{1 t}}{Q_{1 t}}=\frac{W e^{(r-\rho) t}}{a} \\
C_{2 t}=\frac{W_{t} L_{2 t}}{Q_{2 t}}=\frac{W}{b} \\
C_{1 t} Q_{1 t}=\left(\frac{W^{e(r-\rho) t}}{a}\right)\left(a e^{\rho t} L_{1 t}\right)=W e^{r t} L_{1 t} \\
C_{2 t} Q_{2 t}=\left(\frac{W}{b}\right)\left(b e^{r t} L_{2 t}\right)=W e^{r t} L_{2 t}
\end{gathered}
$$

Lindbeck (2006) assumes a balanced budget for the slow-progressive sector. Tax rate $(\tau)$ equals the ratio of public to total costs of the economy. Equation (8) gives the tax rate. 


$$
\tau=\frac{C_{1 t} Q_{1 t}}{C_{1 t} Q_{1 t}+C_{2 t} Q_{2 t}}=\frac{W e^{r t} L_{1 t}}{W e^{r t} L_{1 t}+W e^{r t} L_{2 t}}=\frac{L_{1 t}}{L_{1 t}+L_{2 t}}
$$

Equation (8) can be expressed in terms of the output variables $Q_{i t}$. Rewriting equation (8) in this manner (cf. equations 6 and 7) will provide us with equation (9).

$$
\tau=\frac{Q_{1 t} \frac{W e^{(r-\rho) t}}{a}}{Q_{1 t} \frac{W e^{(r-\rho) t}}{a}+Q_{2 t} \frac{W}{b}}=\frac{1}{1+\frac{a Q_{2 t}}{b Q_{1 t}} e^{(\rho-r) t}}
$$

\section{Wage rates}

We will now assume that while workers in different sectors of the economy originally enjoy equal wages $W_{0}$, the rate of growth of wages will be different in the two sectors. In the fast-progressive sector, it continues to follow the lead of the rate of growth of productivity $(r)$, but in the slow-progressive sector, the rate of growth of wages $(\phi)$ falls between $r$ and $\rho, r>\phi>\rho$.

The assumption corresponds to the original intimation by Baumol and Bowen (1966) as probably the most realistic assumption as regards the development of wages in the slow-progressive sector. Here, we merely formalize their idea.

The idea can be readily expressed in terms of the differential rates depicted above. Having considered two other alternatives, first the one in which $r>\phi=\rho=0$ and second the one in which $r=\phi>\rho=0$, Baumol and Bowen (1966) went on to write, "There is a third alternative, which, in fact, comes closest to what we find in practice. Wages of performers do rise, but they do not always manage to keep up with wages in the rest of the economy. (...) Even in the long run, earnings in the performing arts may lag behind wages in occupations which provide less in the way of psychic income" (Baumol and Bowen, 1966, p. 169).

So, while equations (1) and (2) stay as they are, we will rewrite equation (3) as equations (3'.a) and (3'.b).

$$
\begin{aligned}
& W_{1 t}=W_{0} e^{\phi t} \\
& W_{2 t}=W_{0} e^{r t}
\end{aligned}
$$

The unit cost and total cost equations will be slightly different from Lindbeck's (2006) model and will be rewritten as in (4'), (5'), (6'), and (7').

$$
\begin{gathered}
C_{1 t}=\frac{W_{t} L_{1 t}}{Q_{1 t}}=\frac{W_{0} e^{(\phi-\rho) t}}{a} \\
C_{2 t}=\frac{W_{t} L_{2 t}}{Q_{2 t}}=\frac{W_{0}}{b}
\end{gathered}
$$




$$
\begin{gathered}
C_{1 t} Q_{1 t}=\left(\frac{W_{0} e^{(\phi-\rho) t}}{a}\right)\left(a e^{\rho t} L_{1 t}\right)=W_{0} e^{\phi t} L_{1 t} \\
C_{2 t} Q_{2 t}=\left(\frac{W_{0}}{b}\right)\left(b e^{r t} L_{2 t}\right)=W_{0} e^{r t} L_{2 t}
\end{gathered}
$$

The tax equations come out in the form of ( $\left.8^{\prime}\right)$ and (9').

$$
\begin{gathered}
\tau=\frac{C_{1 t} Q_{1 t}}{C_{1 t} Q_{1 t}+C_{2 t} Q_{2 t}}=\frac{W_{0} e^{\phi t} L_{1 t}}{W_{0} e^{\phi t} L_{1 t}+W_{0} e^{r t} L_{2 t}}=\frac{1}{1+\frac{L_{2 t}}{L_{1 t}} e^{(r-\phi) t}} \\
\tau=\frac{Q_{1 t} \frac{W_{0} e^{(\phi-\rho) t}}{a}}{Q_{1 t} \frac{W_{0} e^{(\phi-\rho) t}}{a}+Q_{2 t} \frac{W_{0}}{b}}=\frac{1}{1+\frac{a Q_{2 t}}{b Q_{1 t}} e^{(\rho-\phi) t}}
\end{gathered}
$$

Note that if the rate of growth of wages in the slow-progressive sector of the economy actually ranges between $\phi$ and $r$, within the range of those particular periods that $\phi$ reaches $r(\phi=r)$, the Lindbeck (2006) model and our own model come together again. Equation ( $\left.8^{\prime}\right)$ reduces to equation (8). The same applies to equation (9') in relation to equation (9).

The model demonstrates that there is an analytically feasible and empirically plausible domain of parameters in which the tax rate of the economy $(\tau)$ reaches its all-time high, while, at the same time, employees in the slow-progressive sector suffer from lower-than-average wages, $(r-\phi)>0$, and while, still in the same domain of parameters, the organizations and employees in the sector have to deal with persistent and often stern productivity pressure, $(\phi-\rho)>0$.

\section{Data}

Finnish Labour Review (2011) No. 1/2011, Tables. Available at http://www.tem.fi/files/29377/ tak12011.pdf (Accessed November 16, 2011).

ISCO (1988) International Standard Classification of Occupations, 1988. http://www.ilo.org/ public/english/bureau/stat/isco/isco88/major.htm (Accessed February 18, 2013).

ISSP Work Orientations III (2005) FSD2287: International Social Survey Programme: Work Orientations III, 2005 [electronic data]. Version 1.0 (2007-09-12). Madrid: Anàlisis Sociòlógicos, Económicos y Politicos, S. A. (JDS/ASEP); Köln: Zentralarchiv für Empirische Sozialforschung [producers, delivery], 2007. Tampere: Yhteiskuntatieteellinen tietoarkisto [delivery], 2007.

PWT 7.0 Alan Heston, Robert Summers and Bettina Aten, Penn World Table Version 7.0, Center for International Comparisons of Production, Income and Prices at the University of Pennsylvania, June (2011) XLS. Available at http://pwt.econ.upenn.edu/ (Accessed November 16, 2011). 


\section{References}

Baumol, H. and Baumol, W. J. (1984/1997) The Mass Media and the Cost Disease. In Towse, R. (ed.) 1997, Baumol's Cost Disease: The Arts and Other Victims. Cheltenham: Elgar, pp. 180-194.

Baumol, H. and Baumol, W. J. (1985/1997) On the Cost Disease and Its True Policy Implications for the Arts. In Towse, R. (ed.) 1997, Baumol's Cost Disease: The Arts and Other Victims. Cheltenham: Elgar, pp. 213-224.

Baumol, W. J. (1967) 'Macroeconomics of Unbalanced Growth: The Anatomy of Urban Crisis', The American Economic Review 57(3): 415-426.

Baumol, W. J. (1972/1997) Macroeconomics of Unbalanced Growth: Reply. In Towse, R. (ed.) 1997, Baumol's Cost Disease: The Arts and Other Victims. Cheltenham: Elgar, p. 81.

Baumol, W. J. (1992/1997) A Growing Economy Can Pay Its Bills. In Towse, R. (ed.) 1997, Baumol's Cost Disease: The Arts and Other Victims. Cheltenham: Elgar, pp. 507-509

Baumol, W. J. (1993a) 'Health Care, Education and the Cost Disease: A Looming Crisis for Public Choice', Public Choice 77(1): 17-28.

Baumol, W. J. (1993b) 'Social Wants and Dismal Science: The Curious Case of the Climbing Costs of Health and Teaching', Proceedings of the American Philosophical Society 137(4): 612-637.

Baumol, W. J. (1996) 'Children of Performing Arts, The Economic Dilemma: The Climbing Costs of Health Care and Education', Journal of Cultural Economics 20(3): 183-206.

Baumol, W. J. (2012), with contributions by David de Ferranti, Monte Malach, Ariel PablosMéndez, Hilary Tabish, and Lilian Gomory Wu, The Cost Disease. Why Computers Get Cheaper and Health Care Doesn't. New Haven \& London: Yale University Press.

Baumol, W. J. and Bowen, W. G. (1965/1997) On the Performing Arts: The Anatomy of Their Economic Problems. In Towse, R. (ed.) 1997, Baumol's Cost Disease: The Arts and Other Victims. Cheltenham: Elgar, pp. 43-50.

Baumol, W. J. and Bowen, W. G. (1966) Performing Arts-The Economic Dilemma. A Study of Problems Common to Theater, Opera, Music and Dance. First published in 1966, the M.I.T. paperback edition in August 1968. Cambridge, MA: The M.I.T. Press.

Baumol, W. J. and Oates, W. E. (1972/1997) The Cost Disease of the Personal Services and the Quality of Life. In Towse, R. (ed.) 1997, Baumol's Cost Disease: The Arts and Other Victims. Cheltenham: Elgar, pp. 82-92.

Baumol, W. J. and Throsby, D. (2012) 'Psychic Payoffs, Overpriced Assets, and Underpaid Superstars', Kyklos 65(3): 313-326.

Baumol, W. J., Blackman, S. A. B., and Wolff, E. N. (1985) 'Unbalanced Growth Revisited: Asymptotic Stagnancy and New Evidence', The American Economic Review 75(4): 806-817.

Besharov, G. (2005) 'The Outbreak of the Cost Disease: Baumol and Bowen's Founding of Cultural Economics', History of Political Economy 37(3): 413-430.

Blaug, M. (2001) 'Where Are We Now on Cultural Economics?' Journal of Economic Surveys 15(2): 123-143.

Bradford, D. F. (1969/1997) Balance on Unbalanced Growth. In Towse, R. (ed.) 1997, Baumol's Cost Disease: The Arts and Other Victims. Cheltenham: Elgar, pp. 67-80.

Bryson, B. (2010) At Home. A Short History of Private Life. London: Black Swan, Random House.

Clark, C. (1957) The Conditions of Economic Progress. London: McMillan \& Co. Ltd.

Coursey, D. H. and Pandey, S. K. (2007) 'Public Service Motivation Measurement: Testing an Abridged Version of Perry's Proposed Scale', Administration and Society 39(5): 547-568.

Cowen, T. (1996) 'Why I Do Not Believe in the Cost-Disease. Comment on Baumol', Journal of Cultural Economics 20(3): 207, 214. 
Curtis, D. C. A. and Murthy, K. S. R. (1998) 'Economic Growth and Restructuring: a Test of Unbalanced Growth Models 1977-1992', Applied Economic Letters 5(12): 777-780.

Deci, E. L. and Ryan, R. M. (1985) Intrinsic Motivation and Self-Determination in Human Behaviour. New York: Plenum Press.

Esping-Andersen, G. (1990) The Three Worlds of Welfare Capitalism. Cambridge: Polity Press.

Fernandez, R. and Palazuelos, E. (2012) 'European Union Economies Facing "Baumol's Disease" Within the Service Sector', Journal of Common Market Studies 50(2): 231-249.

Ferris, J. S. and West, E. G. (1996) 'The Cost Disease and Government Growth: Qualifications to Baumol', Public Choice 89(1-2): 35-52.

Fordham, B. O. (2003) 'The Political and Economic Sources of Inflation in the American Military Budget', Journal of Conflict Resolution 47(5): 574-593.

Gibbons, R. and Katz, L. (1992) 'Does Unmeasured Ability Explain Inter-Industry Wage Differentials', The Review of Economic Studies 59(3): 515-535.

Gittleman, M. and Pierce, B. (2011) 'Inter-Industry Wage Differentials, Job Content and Unobserved Ability', Industrial and Labor Relations Review 64(2): 356-374.

Gittleman, M. and Wolff, E. N. (1993) 'International Comparisons of Inter-Industry Wage Differentials', Review of Income and Wealth 39(3): 295-312.

Hood, C. (1991) 'A Public Management for All Seasons?', Public Administration 69(Spring): 3-19.

Keren, M. (1972/1997) Macroeconomics of Unbalanced Growth: Comment. In Towse, R. (ed.) 1997, Baumol's Cost Disease: The Arts and Other Victims. Cheltenham: Elgar, p. 63.

Krueger, A. B. and Summers, L. H. (1988) 'Efficiency Wages and the Inter-Industry Wage Structure', Econometrica 56(2): 259-293.

Kuznets, S. (1973) 'Modern Economic Growth: Findings and Reflections', The American Economic Review 63: 247-258.

Lehto, A-M. and Sutela, H. (2008) Työolojen kolme vuosikymmentä. Työolotutkimusten tuloksia 1977-2008 [Three Decades of Working Conditions. Findings of Finnish Quality of Work Life Surveys 1977-2008, in Finnish, also available in an English version]. Helsinki: Tilastokeskus.

Lindbeck, A. (2006) 'Sustainable Social Spending', International Tax and Public Finance 13(4): 303-324.

Maddison, A. (1982) Phases of Capitalist Development. Oxford: Oxford University Press.

Maddison, A. (1991) Dynamic Forces in Capitalist Development. A Long-Run Comparative View. Oxford: Oxford University Press.

Nordhaus, W. D. (2002) Productivity Growth and the New Economy. In Brainard, W. C. and Perry, G. L. (eds.), Brookings Papers on Economic Activity 2. Washington: Brookings Institution Press.

Nordhaus, W. D. (2006) Baumol's Diseases: A Macroeconomic Perspective. NBER Working Paper 12218. Cambridge, MA: NBER.

Oulton N. (2001) 'Must the Growth Rate Decline? Baumol's Unbalanced Growth Revisited', Oxford Economic Papers 53: 605-627.

Peacock, A. (1996) 'The "Manifest Destiny" of the Performing Arts', Journal of Cultural Economics 20(3): 215-224.

Perry, J. L. (1996) 'Measuring Public Service Motivation: An Assessment of Construct Reliability and Validity', Journal of Public Administration, Research \& Theory 6(1): 5-22.

Perry, J. L. and Wise, L. R. (1990) 'The Motivational Bases of Public Service', Public Administration Review 50(3): 367-373.

Pollitt, C. (1990) Performance Indicators, Root and Branch. In Cave, M., Kogan, M. and Smith, R. (eds.), Output and Performance Measurement in Government. The State of the Art. London: Jessica Kingsley Publishers, pp. 167-178. 
Pollitt, C. and Summa, H. (1999) Performance Audit and Public Management Reform. In Pollitt, C., Girre, X., Lonsdale, J., Mul, R., Summa, H., and Waerness, M. Performance or Compliance? Performance Audit and Public Management in Five Countries. Oxford: Oxford University Press, pp. 1-10.

Preston, P. and Sparviero, S. (2009) 'Creative Inputs as the Cause of Baumol's Cost Disease: The Example of Media Services', Journal of Media Economics 22(4): 239-252.

Reilly, K. T. and Zanchi, L. (2003) 'Industry Wage Differentials: How Many, Big and Significant Are They?' International Journal of Manpower 24(4): 367-398.

Robinson, J. (1969) 'Macroeconomics of Unbalanced Growth: A Belated Comment', The American Economic Review 59(4): 632.

Roy, A. D. (1950) 'The Distribution of Earnings and of Individual Output', The Economic Journal 60(3): 489-505.

Roy, A. D. (1951) 'Some Thoughts on the Distribution of Earnings', Oxford Economic Papers 3(2): 135-146.

Ryan, R. M. and Deci, E. L. (2000) 'Intrinsic and Extrinsic Motivations: Classic Definitions and New Directions', Contemporary Educational Psychology 25(1): 54-67.

Scitovsky, A. and Scitovsky, T. (1959) 'What Price Economic Progress?', Yale Review, 49(1): 95-110.

Sparviero, S. and Preston, P. (2010) 'Creativity and the Positive Reading of Baumol Cost Disease', The Service Industries Journal 30(11): 1903-1917.

Thomas, K. W. (2002) Intrinsic Motivation at Work. Building Energy and Commitment. San Francisco, CA: Berrett-Koehler Publishers.

Towse, R. (ed.) (1997) Baumol's Cost Disease: The Arts and Other Victims. Cheltenham: Elgar.

Triplett, J. E. and Bosworth, B. P. (2003) 'Productivity Measurement Issues in Services Industries: "Baumol's Disease" Has Been Cured', FRBNY Policy Review 9(Sept.): 23-33.

van der Ploeg, F. (2006) Sustainable Social Spending in a Greying Economy with Stagnant Public Services: Baumol's Cost Disease Revisited. CESifo Working Paper, No. 1822. Http://hdl.handle.net/10419/25867, PDF (Accessed November 21, 2012).

van Reenen, P. (1999) 'The “unpayable” police', Policing: An International Journal of Police Strategies \& Management 22(2): 133-151.

\section{End notes}

1 Theater, opera, music, and dance.

2 For an interesting explanation of the skewed distribution of earnings in challenging occupations, see Roy $(1950,1951)$.

3 Perhaps a primary example of an industry-specific intervening factor is the high price inelasticity (and also high income elasticity) of health care and medication, making massive reallocation, profits, and profit sharing possible in the field.

4 For example, Peacock (1996, p. 218), Curtis and Murthy (1998, p. 780), van Reenen (1999, p. 148), Lindbeck (2006, p. 319), Nordhaus (2006, pp. 36-38), Preston and Sparviero (2009, p. 251), Sparviero and Preston (2010, p. 1910 and passim), and Fernandez and Palazuelos (2012, p. 246).

5 For example, Robinson (1969), Bradford (1969/1997), Keren (1972/1997), Cowen (1996), Ferris and West (1996), Oulton (2001), Nordhaus (2002), and Triplett and Bosworth (2003).

6 Or, in a more refined analysis, a) the production of content, b) the packaging, marketing, and distributing of media content, and c) the delivery and exhibition of content (Preston and Sparviero, 2009, pp. 245-246).

7 What we actually see happening here is that Baumol's (1967) originally abstract macroeconomic model is interpreted more precisely and receives niche support from concrete, disaggregated analyses. 
This could have actually been anticipated on the basis of Peacock's (1996) scholarly scrutiny of the methodological genre of Baumol's work. Peacock referred to the "Malthusian" nature of Baumol's economics. According to him, Baumol has been attracted to "courageously simplified" models and to the "broad sweep" of classical dynamics. Such models either thrive or die as the scholarly community proceeds to more detailed empirical analyses.

8 The results from the analyses of inter-industry wage differentials, which are briefly reviewed in this paper, appear to contradict the conclusions offered by Nordhaus (2006). This may, however, have to do with the differences in the levels, vis-à-vis the rates of growth, of wages. The former kinds of differences have been accumulating for a long time; the major differences in the levels of wages may have been brought about by minor differences in the rates of growth of wages.

9 Van der Ploeg (2006) offers a detailed, but less accessible, theoretical analysis of sustainable social spending.

10 There are several other kinds of manifestations to refer to. Product variety may be reduced. In theater and musicals, cast sizes have been observed to be secularly contracting (Baumol and Baumol, 1985/1997, pp. 220-222). Prices may shoot up with distinct, selective effects on consumption. Common handicrafts of earlier days are modern luxury products; craftsmanship bears the mark of distinguished rarity nowadays. Productive activities in an industry or in an occupation may come to an end. This is what has happened in private personal services; butler, manservant, and maid are unknown entries to modern classifications of occupations (Bill Bryson provides us with a charming historical account of private personal services; see Bryson, 2010, pp. 134-166). Compromising over the quality of the end product is yet another way of dealing with productivity pressure, especially in economic activities in which consumers are not in a position to directly punish low-quality producers (monopolies, oligopolies, public services). Also, slowly but surely, productivity has become an issue and a real intellectual puzzle in public management, much in line with the doctrine of New Public Management and the early ideas of the National Audit Office and the Audit Commission, but not restricted to the Anglo-Saxon countries (Hood, 1991; Pollitt, 1990; Pollitt and Summa, 1999).

${ }^{11}$ Finland was and still is closely attached to the so-called "Scandinavian welfare state regime" (on the concept, see Esping-Andersen, 1990).

${ }_{12}$ For the English version, see http://www.stat.fi/tup/julkaisut/tiedostot/working_conditions.pdf

${ }^{13}$ Lehto and Sutela (2008) further note that findings from the European Working Conditions Survey point to the same direction. The share of respondents who had to "work to tight deadlines at least $1 / 4$ of the time" went up from 49\% (1990, EU10) to 62\% (2005, EU25).

14 There is nothing new to the first part of the argument. Kenneth W. Thomas (2002, p. 118, and passim), for example, has explicitly noted that, while more pay is certainly better than less (other things being equal), it is perfectly possible for the differences in pay to be outweighed by the intrinsic rewards that the lower paying jobs may have to offer. The idea of compensating differences was introduced to the classical political economy by Adam Smith.

15 We thank the anonymous referee of our article for pointing out the argument of this paragraph.

16 The relationship between (1) GDP per capita and personal importance of high income is closer than that between (2) GDP per capita and personal importance of an interesting job. Yet, $R^{2}$ of the model grows a bit when the focus shifts from the high-income approach (i.e., model 1) to the ratio approach (i.e., to the model in Figure 2).

17 Unfortunately, there were not enough choreographers and dancers in the data set.

18 The difference from the norm score (zero) was not statistically significant in any of these three cases.

19 "Two features of the advanced economy have important cultural and social implications. (...)," according to Scitovsky and Scitovsky $(1959$, p. 96), “(...) One is high cost of labor, the other large scale organization and extreme specialization.” 